\title{
Economy of National Security: A Case Study of Pakistan
}

\author{
Khalil-ur-Rehman and Dr. Amanat A. Jalbani \\ SZABIST \\ Karachi, Pakistan
}

\begin{abstract}
:
For the reasons of history, religion, language, culture, aspirations, geopolitics and power; conscious and considered decisions put a country and its economy on a chosen path. The greater context is always Development State v.s., Security State. Pakistan is no exception. On its creation, Pakistan could have moved in the direction of Development State, but it did not. Perhaps the burden of sub-conscious was too much to ignore. It opted for Economy of National Security i.e., power struggle. Over the decades, Pakistan's economy became a combination of national and external resource allocations for the reasons of global geo-politics. Previously, it was Cold War, now it is War on Terror. National capacity of the resource allocation has been stretched to its maximum. Domestically, it led to political and religious reductionism. In foreign policy, the choices made were of Cold War, military buildup, nuclear weapons, delivery systems and alliances in the quest for security and geopolitical status. Has Pakistan succeeded? The problem is that the centre of gravity of American War on Terror and nuclear proliferation is Pakistan itself.
\end{abstract}

\section{INTRODUCTION}

Nation-state and its management is a great abstraction. The quasi one is more so because it lacks strategic and economic sovereignty. The types of nation-states visible today are Development, Declining and National Security state. For example Sweden and Malaysia are development and welfare states. Russian Federation is a declining state. Whereas USA and UK are development as well as national security states, some are amalgam of national security and decline. Pakistan and Israel are classic national security states. Everything is identical about Pakistan and Israel except the successes.

National security state or economy of national security gives priority to defense expenditure over economic development. The verified hypothesis in case of economy of national security is that "the economic capacity of a nation plays a far less important role in determining the course of the power struggle than is generally supposed" [1]. National security state is always preparing for war owing to power struggle. Development state socially, politically and economically is vibrant and progressive. The declining is in a state of decadence. Elements of national power and underlying assumption in each case are different. Some times assumption becomes reality.

In the struggle for power, misconceptions become errors e.g., Pakistan's role in the post-Soviet Afghanistan and American misconception about post-Saddam Iraq are strategic errors. Tactical measures are not working to crush insurgency in Iraq and elsewhere. Strategic errors are rectified through strategic actions. The failure to identify the centre of gravity of Iraqi insurgency is an indicator of what? It is compounding of the error. An aspect of strategy and logic of war is the correct identification of the centre of gravity. When it falls, the resistance diminishes. How to deal with the insurrectional war is the strategic question of the $21^{\text {st }}$ century?

The plan to deal has to have an intuitive element. The assumption that insurrection is rooted in the head of the leader has proved wrong. Escalation or enlarging the conflict is part of strategy but has not worked e.g., Fallujah. The centre of gravity could be intangible. It can be beyond the manifest and has more to it than the eyes encounter. America and its allies including Pakistan will have to shift to the intangibles.

The centre of gravity of anti American insurgency around the Islamic world is US policy towards Palestine, Kashmir, Chechnia, Mindanao, Xinjiang, Algeria, Bosnia, East Timor, Aech, Saudi Arabia, Somalia, Sudan, Afghanistan, and Iraq [2], include Fallujah and its Knights. Oil, sanctions, interventions, aggressions, tyrannies, dictators, kings and monarchs as well, as opposed to American centre of gravity which is economy [2].

In South Asia, Washington has taken measures to enhance its ties to India and simultaneously coerce Pakistan to halt aid for Muslim Kashmiri insurgents, thereby giving de facto sanction to India's sorry record of abusing its Kashmiri Muslim citizens, as well as its Israel-like refusal to obey long-standing UN resolutions on Kashmir [2].

This is neo-Orientalism. Islamic world is under assault since centuries. America is no more a Republic or City on the Hill. The perpetuation of memory of oppression at Abu Gharib through different means and execution of unarmed wounded in the mosques of Fallujah is pathology i.e., sickness. The ambience of the Islamic resistance and insurgency is existential, global, asymmetric and defensive. In Islamic world, the death of the five sensory man and future has already happened. Clausewitzianism is dead. This is the Age of Sixth Sense i.e., intuition. The heart of it is suicide bomber, the intuitive rather than the five-sensory man. It is a new military dimension based on intuition, faith and will.

In the affairs of state, single strategic error is decisive. The strategic errors by the chief oligarch in Pakistan includes: Kargil, deposing elected prime minister, agreeing to American demands without consultation in the post 9/11 hours, referendum, elections, yielding too much to India and military operations in the Federally Administered Tribal Areas (FATA). Any compromise on the nuclear issue is beyond the bounds of strategy. 


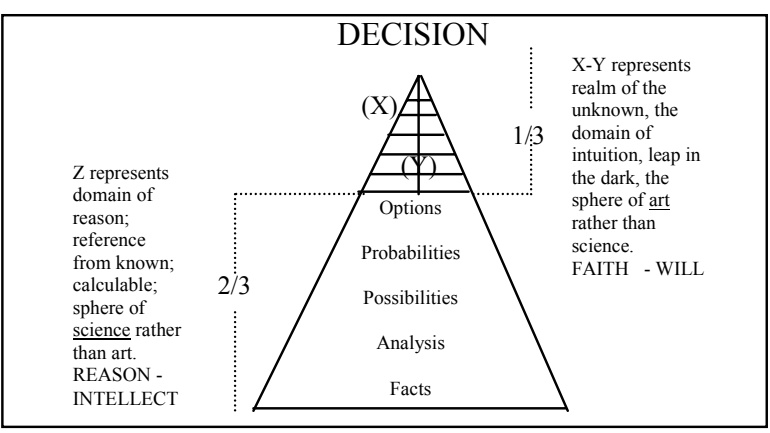

Source: $\quad$ Lectures on Strategy. Decision Making, By Sahabzada Mohammad Yaqub Khan Chapter-7 p.14

There appears to be a temptation to tackle strategic errors through tactical devices e.g., agreement with right wing opposition, change of prime minister, military cantonments in Balochistan, the issue of uniform and as the case may be, national elections in 2005. The dangerous would be the emergence of trans-cis Indus divide as a result of any national elections.

Due to these strategic errors, Pakistan's capacity to execute any policy is limited and going the whole hog is bad strategy. The contradictions have reached a stage where collapse or breakdown will be under the weight of its own friction. Lahore declaration could not be undone. America is part of the Indo-Pak dialogue as a political arbiter. Earlier it was not. Nuclear tests and Lahore declaration were independent developments. The oligarchy is trying to make virtue out of necessity.

States branch out from worldview, which springs from historical experience. Any worldview is a philosophic outlook towards life as a whole. It is culture. Language generates consciousness to further the worldview. The example could be the role of English and sister European languages in furthering modernity. The essence of modern industrial revolution and scientific inventions can be traced back to these languages. The failure of other languages to be scientific is obvious. Nature and structure of each language is different and with its own logic. National aspirations are expressions of the worldview and consciousness.

Economy is the pedestal of this linguistic and cultural expression. This makes resource allocation central to the nature of state and economy. To justify, ideologies and security perceptions play a critical role. Minds turn prisons e.g., Cartesian-Newtonian prison. These prisons have open gates, yet few escapes. Imagination straggles. If this is not so then why this chaos is all around the world? Why does every one take this royal road? The gaining and regaining of honors can be in creative ways as well. Sense of inferiority is part of human conscious and subconscious. That bone deep insecurity.

Without much success, oligarchy in Pakistan continues to believe in the power struggle — internally as well as externally. A military mind understands the articulation of power, not that of human development or sovereignty. The concept of sovereignty and its location is a philosophic idea. It took a revolution to displace it in the west. Islamic world has a thirst for a symbol to locate sovereignty. The earlier the penny drops in the military mind, the better it is.

Pakistan's problem is that "a largely agriculture economy, irrespective of its wealth, lacks the industrial facilities to produce the weapons necessary for modern warfare; it can only acquire them from other sources"[3]. Pakistan is a peasant cum tribal society. Its gestalt thinking is without an industrial and scientific base. There is a palpable gap. To be industrial, one has to be modern and soil of the Islamic world is inhospitable to modernity and its indulgences. What good does it do to adjust and integrate the self in a culture that is itself sick [4].

This study is:

- To elucidate upon the economy of national security.

- To analyze Pakistan as an economy of national security.

- To look into the future prospects of Pakistan's economy of national security.

\section{ECONOMY OF NATIONAL SECURITY: AN OVERVIEW}

Economic analysis is not - as it is frequently, but erroneously, believed to be - concerned solely with the satisfaction of material wants [5]. On the contrary, the fundamental issue with which it deals is that of choice, a phenomenon that transcends the material realm [5]. The choice a country makes represents the outlook of the state and economy. It is a conscious decision. And state policies do not change with the change in governments. Minds are cascaded and refuse to acknowledge facts.

Every nation creates a reality. It feels its way towards that reality. Rambling and wondering through linguistic fields reveal these realities. Worldview of a nation and language's relation is vital. For all beginnings are with thought and language. Pakistan created its own reality. The dynamics of the 9/11 led to compromise. Pakistan's wants and desires are limitless but it is not ready to sacrifice, even fight. A Hamlet is being played in which the Prince of Denmark has a patience of a coward. Torn between the past and present, the split soul is experiencing the cleavage, rage and anger.

In the present global framework, security is presented as the critical core. The Davos Summit 2004 stressed on security. It is visible in the top fifteen defense spenders having serious problems among themselves. The problems and contestants are co and cross co-related in the power struggle. The end of the Cold War points toward 'design' rather than of 'scheme', towards purposeful creation rather than acceptance of some natural or inevitable state of affairs [6]. 
In such settings, economy of national security is important for those who wield power. The chances of transcendence are bleak. The unilateral hegemonic cycle is witnessing series of wars. Tragedy is not between state and religion but at the very heart of being [7]. Being creates around him a field of force e.g., neo-cons. No country can give itself a new past [8], but it can alter the future [8]. A cursory glance at the figures reflects on the economies of national security. The ruling elite in these countries perceives stakes in the power struggle. Data below are indicators and current expenditures are beyond these figures.

Table: Top 15 defense spender countries in 2002

\begin{tabular}{|l|l|l|}
\hline \multicolumn{2}{|c|}{ Ranking in $\begin{array}{c}\text { PPP (power purchase parity) } \\
\text { dollar terms }\end{array}$} \\
\hline Rank & Country & Size (\$b) \\
\hline 1 & USA & 335.7 \\
\hline 2 & China & 142.9 \\
\hline 3 & India & 66.9 \\
\hline 4 & Russia & 55.4 \\
\hline 5 & France & 36.8 \\
\hline 6 & UK & 34.0 \\
\hline 7 & Japan & 32.8 \\
\hline 8 & Germany & 31.0 \\
\hline 9 & Saudi Arabia & 28.8 \\
\hline 10 & Italy & 26.9 \\
\hline 11 & South Korea & 24.3 \\
\hline 12 & Turkey & 23.0 \\
\hline 13 & Brazil & 22.8 \\
\hline 14 & Iran & 20.2 \\
\hline 15 & Pakistan & 14.2 \\
\hline
\end{tabular}

Sources: Military expenditure: SIPRI Yearbook 2003, appendix 10A; PPP rates: World Bank, World Development Indicators 2002 (World Bank: Washington, DC, 2002).

\section{PAKISTAN: AN ECONOMY OF NATIONAL SECURITY}

Creation of Pakistan is manifestation of a worldview. The role of religion is critical. Any study of Pakistan's foreign policy reflects two influences: aspirations and India. A nation's foreign policy is, to be sure, a reflection of its internal compulsions [9]. Aspirations and pre-occupation with India led to heavy defense expenditure. The unifying bonds have been these two factors. The aspirations are trans-national, trans-cultural and trans-geographic. It is a way of life, deductive process of reasoning as well, stemming from language. Urdu language and the consciousness generated by it are canted towards power struggle. The passions and lacerations of Pakistani consciousness are Pan-Islamic. Learning a language alters the mind. One lives in a language and breathes in its worldview. Most of the struggles in contemporary times arise from within and are local, whereas pan-Islamic is global. Why it did not occur to Iqbal that pan-Islamic worldview has to be reconciled with the nation-state? After 9/11, the choice is between Ghalib and Iqbal. The past is not dead and future is uncertain; whereas the present speaks for itself.

Starting from Southeast Asia Collective Defense Treaty (SEATO) and Central Treaty Organization (CENTO), the resource utilization indicates. During the 1980s Pakistan received about $\$ 25$ billion (a conservative estimate) from various sources and most of these sources were totally unencumbered [10]. The total amount spent on the bomb, the missiles and the two low intensity conflicts would certainly be more than $\$ 10$ billion-more likely about $\$$ 15 billion [10]. The rest (of the $\$ 25$ billion) was perhaps pocketed by the people who ran the first Afghan war from Pakistan on behalf of the US and CIA [10]. A large part of the $\$ 11$ billion (confiscated after the nuclear tests) was also diverted to the two clandestine programs and the two low intensity wars [10].

Successive governments being unable to reduce their unproductive expenditure chose instead to reduce development expenditure which fell from an average of 7.4 percent of GDP during the period 1973-1977 to only 3.4 percent of GDP in the period 1997-98 to $1999-2000$ [11]. Thus politics - the exercise of power determines economics - the distribution of material values [12].

It is not different today but with a variance. In American perception success in war on terror "depends far more on worldwide cooperation and on dealing more effectively with friends - notably Pakistan and Saudi Arabia, where the threat from terrorism and the diffusion of WMD is and was greater than in Iraq — rather than with our enemies"[13]. Allies tackle problems and not each other. In Camp David the two perceptions blamed each other and later as well during the annual UN Summit 2004.

The support base for pro-American foreign policy in Pakistan is 2 percent [14]; yet the defense expenditure is on the rise. The increase in the defence budget of Pakistan for 2004-05 is Rs.13 billion i.e., 7\%. In 2004, Pakistan's defense expenditure, which amounted to $54.5 \%$ of the total annual allocation, has outpaced development expenditure, which stood at 35.5\% [15]. The proposed arms sale to Pakistan by USA in 2005 is estimated at $\$ 1.3$ billion.

The centre of gravity of Pakistan's armed forces has shifted from the east against India to the west and against its own people. It is like playing fidelity. It is a new phase ideologically as well as militarily. From conventional warfare, the paradigm shift is towards counter-insurgency and guerilla warfare. The shift in the centre of gravity of American war in Afghanistan to Pakistan is conspicuous. Military operations in FATA will have repercussions. Success through economy of national security is temporary and tactical. Loss is long term and strategic. Balanced convergence of the two is required.

States might be essentially the possession of certain lineages or clans, oligarchies or ruling classes [16]. Questions of war and peace might be largely their private concerns, having little to do with "whole societies" [16]. The question of war and peace cannot be understood anywhere in the recent or contemporary world without studying, in addition to states, the overlapping networks of 
social interactions, the competing approximations to a 'society' offered by nations, continental civilizations, religions and self styled races [16].

The realism and anarchy of the nation-state makes it easier for the oligarchy to justify control, masquerading as national interest. Pakistan needs to weigh as to what are the chances of emerging as an enemy state? How to absorb the potential partition of Afghanistan? No country or economy is without problems. The endeavor should be that it does not turn into tragedy. The national security state is a natural favorite of the advocates of private tyrannies because the device facilitates transfer of public funds to advanced industry and to wealthy sectors generally, with the public cowering in fear of foreign enemies so that planners can operate in 'technocratic insulation' [17].

\section{CONCLUSION/RECOMMENDATIONS}

Pakistan's economy of national security failed to achieve its objectives. During Kargil Pakistan's nuclear weapons could not force India into negotiations or restrain it from threatening military postures subsequently. It was the cease-fire across the Line of Control (LoC) which did the trick. If this is not so then why did Indian army go back in 2002 ? Though it is well short of Indian expectations. What are the constellations of circumstances that will convey to Indians what they expect? As long as there are 700,000 troops in the Indian held Kashmir the dagger remains pointed at Pakistan's heart. The troop reduction by Indians is symbolic. The American perception includes "significant regional wars fought with highly lethal weaponry, for example between India and Pakistan or between Israel and Iran" [18]. The disparity of the two relationships, Indo-US and Pak-US, is the context in which events in South Asia are unfolding. The only choice left with Pakistan is to cry wolf.

Indians are looking forward to a peace process whereas chief oligarch wants an event to take place. The skipping of the premises will not work. How can a deep-rooted agreement take place where apex of the pyramid is involved and masses are not participating. The two should understand each other's threshold of tolerance. It is a political judgement. Is Kashmir the beginning or end of everything between the two?

Pakistan's liberty of manoeuvre is non-existent. No Pakistani card is on the table that has been won on the battlefield. The winning of war is different from military defeat, which is traumatic. It permeates into the bone and marrow of nations. The iron of it enters the soul. Americans are sold to the idea of turning $\mathrm{LoC}$ into an international border.

Pakistan's best alternative to negotiated agreement is none, whereas in case of India it is more than one including war. It is difficult to imagine India being deeply invaded or pinned down for long by the conventional military forces of Pakistan [19]. In the absence of international restraints, the reverse is entirely plausible [19]. Even in the presence of nuclear sovereignty, that is questionable, the assumption appears plausible. Military imbalances are balanced through moral forces.

Now War on Terror, which is perceived by the west as anti-American Islamic insurgency. It is global in its reach and grasp. The struggle is between the two worldviews. It is religion v.s., science. It is deduction v.s., induction. Deduction posits whereas induction examines the truth. At what stage induction starts? This is the last encounter until something else comes up. Dynamics have already taken over. The tremendous transformations of the $21^{\text {st }}$ century unleashed by 9/11 have unpinnioned wings of an Eagle. After all those who lived during French Revolution never knew about it. The chain of events triggered would change the world dramatically, particularly Islamic world.

In Pakistani and Afghan context, Pathan heartland is the main battlefield. In Afghanistan “America's staying-on also all but ensures the unraveling of Pakistan and perhaps a civil war there"[20]. Waziristan represents the ethyl alcohol of Pathan culture. Why is it being concealed? Is it concealment of the failure? The mixture of Pathan ethnicity and religious extremism is dangerous. Pathans are intuitive and understand the dimensions of power. Historically, they fought for it, acquired it, possessed it, applied it, resisted it and of course are still resisting it. There is this culture of resistance and non-conformity, compared to that of giving safe passage. The Gods have ordained a riddle worthy of old Oedipus which all Empires must solve or fall --- the riddle of the Northwest Frontier [21].

Pakistan needs a Centaur who can combine charisma and leadership to save it from the credulity of the Oedipus. When a society is suggestible then it is credulous. Somehow certain societies are more liable to be unconscious of important things. Pakistan's regional and global relationships can be best phrased as emphasizing positive while de-emphasizing negative. In power struggle, remoteness is not the function of distance. It is the lack of power and influence. Like a mystique, Pakistan is going through the dark night, the night of the trial. The approaching decisions will try its soul.

Additionally, not enough control over the instrument of craft i.e., language by the highest in Pakistan is disturbing. It is the absence of gravitas and repartee. The use of double adjectives in case of enlightened moderation is bad English i.e., tautology. The majesty of English is in the least use of adjectives. The banalities devoid of imagination are torturous. Let alone disharmony in the convergence of thought and language. The pressures are chastening and perplexity is visible.

For Waziristan, intended flank protection in Balochistan by means of military cantonments is leading to more problems. The lack of understanding of the operational environment is evident. In the context of global power 
struggle, the problem in Balochistan appears to be a move to counter Gwadar. The selection of timing by the Baluchi nationalist leadership reflects their understanding of the power struggle.

Domestically this is the last battle of the establishment. Long term American interests does not coincide with oligarchy. After 9/11, Americans wanted Pakistan to lead the Organization of Islamic Conference (OIC) but it failed. The dimension of time acts like a solvent in decision making. If one goes back in history, it judges by answering as to what were the cards and how were those played?

Oil throws Islamic world willy-nilly into confrontation with the west e.g., Iraq's emergence like a solitaire diamond surrounded by other diamonds. Pakistan too is caught between the Caspian and Persian Gulf. The Muslim response is based on rage and anger since nation-state is dead in the Islamic world. The death of the five sensory man. It is not so facile a solution. Islam in its heart carries a flexibility of the level of Hudabia. Islamic world has consensus but lacks cohesion. The metaphysical divide is unfortunate.

Historically resurgence is accompanied with creative activity. Other than struggle, Islamic world in general and Pakistan in particular needs innovation as well as reforms. It needs an idea pervading the whole space. The recommendations include representative governments, creative imagination, development of Islamic hermeneutics and positivism, tackling reductionism, debate on ethical values and promotion of art that has the power and force of its own. The dream is that of the turning outwards of the Muslim soul i.e., Islamic Renaissance and revival of Islamic Heritage [22].

\section{REFERENCES}

[1] Schlesinger, James R. The Political Economy of National Security, New York: Frederick A. Praeger, publishers. 1982, p. I, 54, 17.

[2] Anonymous. Imperial Hubris. Washington, D.C: Brassey’s, Inc. 2004, pp. 12, 101, 263,225.

[3] Schlesinger, James R. op.cit., p. 54.

[4] Wilber, Ken. A Brief History of Everything, Dublin : Gateway. 2001. P. 125.

[5] Schlesinger, James R. loc.cit., p.17.

[6] Parker, Geoffrey. 'Globalisation and Geopolitical World Orders' in Eleonore Kofman and Gillian Youngs (eds.). Globalisation: Theory and Practice, New York: Pinter. 1996, p. 78.
[7] Heidegger, Martin. That is to Say. Trans. from French by Jan Plug. Stanford: Stanford University Press. 1998, p. 148.

[8] Fareed Zakaria. The Future of Freedom. New York: W.W. Norton \& Company. 2003, p. 69.

[9] Schlesinger, James R. op.cit., p.4.

[10] M. Ziauddin. 'The cost of our N-deterrence-II: story of the clandestine billions', Dawn, Karachi. February 23, 2004. p.6.

[11]UNDP. Pakistan: National Human Development Report, Karachi: Oxford University Press. 2003. p 3.

[12] Kegley, Charles W. \& Eugene R. Wittkopf. World Politics. New York: St. Martin's Press. 1993, p. 209.

[13] Abramowitz, Morton. 'Does Iraq Matter', in The National Interest, Number 75. Washington, DC. 2004, p. 4.

[14] Takeyh, Ray. 'Uncle Sam in the Arab Street', in The National Interest, Number 75. Washington, DC. 2004, p. 48.

[15]Khaleeq Kiani. Defense outpaces development spending, Dawn, Karachi. March 1, 2004. p.12.

[16]Mann, Michael. 'Authoritarian and Liberal Militarism: a contribution from comparative and historical sociology, Ken Booth and Marysia Zalewski (eds.).International Theory: Positivism and Beyond, Cambridge: Cambridge University Press. 1996, p. 222,237.

[17] Chomsky, Noam. Power and Prospects: Reflections on Human Nature and the Social Order. Sydney: Southwood Press Pty Ltd. 1996, p. 124.

[18] Brzezinski, Zbigniew. The Choice, New York: Basic Books. 2004,p.7.

[19]Jones, Rodney W. 'Pakistan's Nuclear Posture: Quest for Assured Nuclear Deterrence' in Charles Kennedy, Kathline McNeil, Carl Ernst, David Gilmartin (eds.) Pakistan at the Millennium, Oxford: Oxford University Press. 2003, pp.319, 320.

[20] Anonymous. op.cit., p. 176.

[21] Mason, A.E.W. The Three Gentlemen. White Plains: Aeon Publishing Company. 1932, p.56.

[22] Bhutto, Zulfikar Ali; The Islamic Heritage; SZABIST Publication, USC, Los Angeles, 1948. 